A N N A L ES

UNIVERSITATIS MARIAE CURIE-SKŁODOWSKA

LUBLIN - POLONIA

VOL. LXVI, 1

SECTIO G

2019

Uniwersytet Marii Curie-Skłodowskiej w Lublinie

GRZEGORZ SMYK

grzegorzsmyk@prawo.umcs.lublin.pl

ORCID: 0000-0003-0143-4233

\title{
Próby zdefiniowania pojęć ,,administracja” i ,prawo administracyjne” w piśmiennictwie prawno-administracyjnym przełomu XIX i XX w.
}

Attempts of Defining the Terms "Administration" and "Administrative Law" in the Legal-Administrative Literature at the Turn of the $19^{\text {th }}$ and $20^{\text {th }}$ Centuries

Powstanie nowoczesnych nauk administracyjnych w XIX stuleciu pozostawało w ścisłym związku z pojawieniem się państwa konstytucyjnego, z jego gwarancjami poszanowania indywidualnych praw podmiotowych jednostki, funkcjonalnym i organizacyjnym podziałem władz publicznych oraz mechanizmami kontroli legalizmu funkcjonowania aparatu państwowego ${ }^{1}$. Wraz z pojawieniem się państwa konstytucyjnego powstała konieczność określenia jego funkcji i zakresu oddziaływania (zwłaszcza w stosunkach wewnętrznych) oraz uregulowania przepisami prawa relacji pomiędzy obywatelem a organami administracyjnymi państwa.

1 Koncepcja państwa konstytucyjnego wywodziła się wprost z ideologii oświecenia, opartej na teorii umowy społecznej, doktrynie prawa natury oraz teorii podziału i kontroli władz publicznych. Najwcześniej została zrealizowana w rewolucyjnej Francji, a w ciągu XIX w. objęła wszystkie (poza Rosją) kraje europejskie, przyjmując powszechnie do końca tego stulecia konstrukcję konstytucyjnego państwa prawa. Andrzej Dziadzio wyróżnił 13 elementów składających się na konstrukcję konstytucyjnego państwa prawa. Są to: 1) prymat konstytucji i ustaw; 2) związanie aparatu państwowego ustawami uchwalanymi przez parlament; 3) sądowo-konstytucyjna ochrona legalności ustaw; 4) suwerenność narodu; 5) podział władz; 6) niezależność sądownictwa; 7) niezawisłość sądów; 8) katalog praw i wolności obywatelskich; 9) sądowo-konstytucyjna ochrona praw zasadniczych obywateli; 10) odpowiedzialność cywilnoprawna państwa za bezprawne działania jego funkcjonariuszy; 11) laicki charakter państwa; 12) samorządowa struktura państwa; 13) sądownictwo administracyjne. Zob. A. Dziadzio, Koncepcja państwa prawa w XIX wieku-idea i rzeczywistość, „Czasopismo Prawno-Historyczne” 2005, nr 1, s. 177-185. 
Najistotniejszym osiągnięciem państwa konstytucyjnego w zakresie interesującej nas problematyki stało się podporządkowanie administracji publicznej rządom prawa oraz nadanie prawu administracyjnemu charakteru systemu norm dwustronnie obowiązujących. Zgodnie z zasadą legalizmu obowiązywanie ustawy zasadniczej, nadrzędnej w stosunku do całego ustawodawstwa krajowego, prowadziło nie tylko do rozdzielenia funkcji ustawodawczych i wykonawczych państwa, ale przede wszystkim do podporządkowania całego aparatu administracyjnego prawu. Administracja państwa konstytucyjnego miała działać na podstawie i w granicach prawa. W zakresie prawa administracyjnego zasada legalizmu oznaczała związanie prawem powszechnie obowiązującym nie tylko obywateli - adresatów decyzji administracyjnych, lecz także organów administracji państwowej².

W pierwszej połowie XIX w. poglądy na administrację publiczną i rolę prawa administracyjnego pozostawały pod silnym wpływem doktryn liberalnych, dążących w tej mierze do maksymalnego ograniczenia wpływu państwa na życie obywateli. Było to wynikiem zarówno reakcji na dominującą w poprzednim stuleciu samowolę państwa policyjnego, jak i przekonania o konieczności zapewnienia jednostce jak najszerszej autonomii, zwłaszcza w dziedzinie stosunków gospodarczych (laissez faire, laissez passer $)^{3}$. Dopiero w drugiej połowie XIX w., pod wpływem rozwijających się żywiołowo procesów demograficznych, gospodarczych i urbanistycznych, pojawiła się konieczność powołania i rozbudowy wielu nowych służb publicznych oraz szczegółowej reglamentacji różnorodnych dziedzin życia społecznego, głównie w sferze gospodarczej i socjalnej. Ta postępująca komplikacja stosunków społecznych i gospodarczych oraz wzrost aktywności administracyjnej państwa pociągnęly za sobą konieczność sformułowania nowych koncepcji w przedmiocie funkcji władzy państwowej, a także wypracowania nowych konstrukcji teoretycznych, w tym tak fundamentalnych pojęć, jak ,administracja” i ,prawo administracyjne"4.

2 Jerzy Malec przypisał prawu administracyjnemu, funkcjonującemu w konstytucyjnym państwie prawa, następujące sześć zasadniczych cech: 1) administracja powinna działać na podstawie i w ramach przepisów prawa ustanowionych w trybie legislacyjnym przez konstytucyjne organy reprezentacji społeczeństwa - parlamenty; 2) normy prawa administracyjnego muszą mieć charakter dwustronnie obowiązujący, tj. muszą wiązać zarówno obywateli, jak i organy administracji państwowej; 3) ustawowe wskazanie zakresu i form ingerencji administracji w sferę praw podmiotowych obywateli; 4) zasada kontroli organu ustawodawczego zwierzchniego aparatu administracyjnego państwa przy zastosowaniu instrumentów odpowiedzialności konstytucyjnej i parlamentarnej ministrów; 5) brak kodyfikacji prawa administracyjnego, wynikający z szerokiego zakresu reglamentacyjnego i stałej dynamiki rozwoju stosunków tej dziedziny prawa; 6) sądownictwo administracyjne jako instrument kontroli przez obywateli sprzecznych z prawem decyzji administracyjnych. Zob. J. Malec, Narodziny polskiego prawa administracyjnego, [w:] idem, Studia z dziejów administracji nowożytnej, Kraków 2003, s. 103.

3 M. Zimmermann, Pojęcie administracji publicznej a „swobodne uznanie”, Poznań 1959, s. 10-15; H. Izdebski, Historia administracji, Warszawa 1997, s. 84-97.

4 J. Jeżewski, Dekoncentracja terytorialna administracji jako zasada prawa administracyjnego we Francji, Wrocław 2004, s. 59-61; M. Gromadzka-Grzegorzewska, Narodziny polskich 
Krajami wyznaczającymi kierunki rozwoju nowoczesnych nauk administracyjnych w XIX w. były Francja i państwa niemieckie. Ze względów politycznych (rozdrobnienie państw niemieckich) wcześniej pojawiły się one we Francji, gdzie tradycyjnie koncentrowano się na zagadnieniach praktycznych stale systematyzowanego prawa administracyjnego, ujmowanych następnie w konstrukcje teoretyczne. W Niemczech aż do drugiej połowy XIX w. problematyka prawa administracyjnego pozostawała w cieniu zainteresowań nauką administracji i jej ścisłym związkiem z konstrukcją państwa prawa (Rechtsstaat). Stąd też, jak zauważa Wojciech Witkowski:

[...] charakterystyczną cechą nauki niemieckiej - aktualną do czasów współczesnych - stało się dążenie do stworzenia teorii administracji, w której prawo administracyjne ujmowane jest jedynie jako jeden z działów prawa, normujący ustrój administracji publicznej i jej oddziaływanie wobec podmiotów postronnych, nacechowany nadrzędnością, wyrażaną w formie aktu administracyjnego ${ }^{5}$.

Z tych względów za ojczyznę nowoczesnej nauki prawa administracyjnego można uznać Francję, a nauk administracyjnych - kraje niemieckie.

Rozwój nowożytnych nauk administracyjnych w XIX w. pociągnął za sobą konieczność określenia ich przedmiotu badawczego oraz zdefiniowania podstawowych pojęć. Wśród tych ostatnich centralnym zagadnieniem stało się zdefiniowanie pojęć ,administracja” i „prawo administracyjne” wraz z określeniem ich podstawowych cech i funkcji. Największe trudności napotykały próby zdefiniowania pojęcia „,administracja” i określenia jego istoty prawnej. W literaturze przedmiotu dominowało dwojakie podejście do tego zagadnienia. Administrację próbowano określać od strony podmiotowej - jako osoby lub zespoły osób wykonujące funkcje administracyjne, organy i inne jednostki administrujące, lub od strony przedmiotowej (funkcjonalnej) - wiążąc pojęcie ,administracji” z aktywnością tych osób, ich zespołów, organów i jednostek administrujących lub też z działalnością państwa i innych podmiotów władzy publicznej. Definicje podmiotowe łączyły pojęcie administracji z zespołem ludzi powiązanym w pewną całość organizacyjną z uwagi na wspólne cele, wyposażonym w pewien zakres uprawnień władczych. W ujęciu tym punktem wyjścia był człowiek działający w ramach szczególnego układu organizacyjnego. W ramach definicji przedmiotowych nawiązywano natomiast do różnych sfer aktywności państwa, podkreślając, że administracja to nie tylko wykonywanie ustaw, lecz także działalność twórcza, będąca jedną z form realizacji funkcji państwa, polegająca na

nauk administracyjnych, Warszawa 1985, s. 21; D. Malec, J. Malec, Historia administracji i myśli administracyjnej, Kraków 2000, s. 117.

5 W. Witkowski, Historia administracji w Polsce 1764-1989, Warszawa 2007, s. 57. 
bezpośrednim, praktycznym wykonywaniu zadań państwa ${ }^{6}$ W konsekwencji $\mathrm{w}$ dziewiętnastowiecznym piśmiennictwie prawno-administracyjnym pojęciem „administracja” określano zarówno organizację aparatu wykonawczo-administracyjnego państwa (ujęcie podmiotowe), jak i różnorodne sfery jego aktywności (ujęcie funkcjonalne), często nie rozróżniając jednak działalności publicznej od zarządzania sprawami prywatnymi. Prowadziło to do zasadniczych rozbieżności w zakreślaniu granic pojęcia „,administracja”, a w wielu wypadkach również do świadomej rezygnacji z konstruowania jej definicji, zastępowanej próbami opisu tego zjawiska?

Wyraźne różnice w podejściu do zagadnienia definicji administracji występowały w literaturze francuskiej i niemieckiej. Charakterystyczne dla piśmiennictwa francuskiego było ujmowanie definicji administracji od strony podmiotowej. Autorzy francuscy tej epoki, tacy jak baron Joseph-Marie de Gérando i Antoine-François Vivien, pojęciu ,administracja” nadawali wąskie znaczenie, w większości utożsamiając je z korpusem urzędniczym lub szerzej - z pojęciem służb publicznych. Stąd też w literaturze francuskiej obok pojęcia „administracja” częściej występowało pojęcie „administracje”, stosowane do określania poszczególnych działów zarządu sprawami publicznymi państwa ${ }^{8}$. Ponadto autorzy francuscy zawężali zakres pojęcia „administracja” jedynie do sfery aktywności państwowego aparatu wykonawczego, realizowanej na szczeblu lokalnym w celu zaspokojenia potrzeb miejscowych społeczności (administracja sensu stricto), wyłączając zeń

6 Współcześnie dominują definicje mieszane - podmiotowo-przedmiotowe, uwzględniające to, że administracja to zarówno określona struktura, jak i szczególne działanie: „Przez administrację publiczną rozumie się zespół działań, czynności i przedsięwzięć organizatorskich i wykonawczych, prowadzonych na rzecz realizacji interesu publicznego przez różne podmioty, organy i instytucje na podstawie ustawy i określonych prawem formach" - H. Izdebski, M. Kulesza, Administracja publiczna. Zagadnienia ogólne, Warszawa 1999, s. 79.

7 Z problemem tym nie potrafił sobie poradzić nawet Lorenz von Stein, który w swoim podręczniku prawa administracyjnego otwarcie stwierdził, że „to, czego nie umiem nazwać, to jest administracja”. Zob. L. von Stein, Handbuch der Verwaltungslehre, Stuttgart 1865-1884, s. 3.

8 Utożsamiając pojęcie ,administracja” z konstrukcją służb publicznych, de Gérando (Institutes de droit administratif français, Vol. 1, Paris 1842, s. 161-162) twierdził, że „administrację publiczną należy uznać za zespół służb podległych władzy politycznej, a wynikających z potrzeb ogólnych społeczeństwa [...]”; wymienił też takie podstawowe służby, jak zarząd finansów, zarząd sił bezpieczeństwa, administracja cywilna. Za jego przykładem administrację określali przy pomocy pojęcia służb publicznych niemal wszyscy późniejsi autorzy francuscy. Jedynie Macarel i Vivien pojęcie administracji stosowali konsekwentnie do określenia funkcji państwa. Macarel (Cours d'administration et de droit administratif, Vol. 1, Paris 1852 s. 13) traktował je jako określenie „władzy wykonawczej w akcji, jako wykonywanie prawa w interesie powszechnym". Vivien (Etudes du droit administratif, Vol. 1, Paris 1859, s. 3) natomiast określał administrację jako ,pełnienie służb publicznych, jako część władzy wykonawczej, która polega na materialnym i praktycznym wykonywaniu tych służb". Niektórzy, jak Anselme-Polycarpe Batbie (Introduction generale au droit public et administratif, Paris 1876, s. 80-81), nie troszcząc się o precyzję terminologiczną, stosowali słowo „administracja” zarówno w znaczeniu podmiotowym, jak i funkcjonalnym. 
całą sferę działalności rządu centralnego, zaliczaną przez nich do władzy politycznej, a nie wykonawczo-administracyjnej (Léon Aucoc, Antoine-François Vivien, Louis-Antoine Macarel) ${ }^{9}$. Niezaprzeczalnym osiągnięciem francuskiej literatury prawno-administracyjnej XIX w. było rozróżnienie pojęć „,administracja” i „policja” oraz wskazanie miejsca prawa administracyjnego w ogólnym systemie prawa pozytywnego. Rozróżniając władzę ustawodawczą, sądowniczą i wykonawczą, francuscy publicyści tę ostatnią podzielili na rządową i administracyjną. W tym ujęciu administracja obejmowała także policję, którą traktowano jedynie jako wyspecjalizowaną część aparatu administracyjnego powołaną dla ochrony porządku i bezpieczeństwa wewnętrznego państwa. Ze względu na funkcje policję dzielono w doktrynie francuskiej na administracyjną (police administrative) i sądową (police judiciaire), podporządkowując tę ostatnią organom wymiaru sprawiedliwości. Zadaniem pierwszej było działanie poprzez środki negatywne w celu zapobieżenia naruszeniom prawa, a drugiej - postępowanie w celu przywrócenia naruszonego prawa. Pod pojęciem ,administracja” w znaczeniu podmiotowym rozumiano ogół służb publicznych państwa, ich strukturę oraz budowę wewnętrzną organów wykonawczo-zarządzających państwa, natomiast w znaczeniu przedmiotowym - zakres jej funkcji reglamentacyjnych. Stąd też wyraźne w literaturze francuskiej rozróżnienie pomiędzy nauką administracji i nauką prawa administracyjnego. Organy administracji dzielono: 1) ze względu na funkcje - na czynne, doradcze i sądowe; 2) ze względu na charakter działalności - na administracyjne i policyjne (przy zachowaniu podziału tych ostatnich na organy policji administracyjnej i sądowej) ${ }^{10}$.

W odróżnieniu od pisarzy francuskich autorzy niemieccy pojęcie administracji ujmowali przede wszystkim od strony funkcjonalnej, ale i oni nie potrafili sprecyzować jednoznacznie, na czym polega jej prawna istota. Pojęcie administracji łączyli głównie z działalnością państwa, różniąc się w zakreślaniu jej granic. Jedni, jak Lorenz von Stein, z administracją utożsamiali wszystkie (poza ustawodawstwem) formy aktywności państwa, łącznie z wymiarem sprawiedliwości

9 Aucoc (Conferences sur l'administration et le droit administratif, Vol. 1, Paris 1869, s. 17) twierdził, że „administracja publiczna dotyczy tylko departamentów, gmin i zakładów publicznych”. Vivien (op. cit., s. 71) zaś przyrównywał władzę polityczną (czyli rządową) do głowy, a administrację - do ramion, pisząc, że ,prezydent, rząd i ministrowie stanowią źródło, z którego wypływa działalność administracyjna, prowadzona na całym terytorium kraju przy pomocy podwójnego systemu organów administracyjnych o kompetencjach ogólnych i kompetencjach specjalnych". Jedynie Macarel (op. cit., Vol. 1, s. 13), wychodząc z założenia, iż „administracja stanowi witalną aktywność rządu, czyli władzy stanowiącej prawa, dążącej do rozwoju społeczeństwa oraz zapewnienia mu bezpieczeństwa i szczęścia”, podkreślał, że należy odróżnić administrację centralną i lokalną, a tym samym nadawał pojęciu ,administracja” szersze znaczenie.

10 Podsumowanie osiągnięć francuskiej nauki prawa administracyjnego w XIX w. zawiera opracowanie Jerzego Langroda, La science de l'administration publique en France aux XIX e. et XX e. siecles, « Revue Administrative »1961, passim. 
i finansami publicznymi ${ }^{11}$. Inni zaś, jak Rudolf Gneist, wyłączali z niej także wymiar sprawiedliwości ${ }^{12}$. Jeszcze inni, jak Otto Mayer czy Walter Jellinek, trudność sformułowania powszechnie akceptowanej definicji pozytywnej próbowali zastąpić definicją negatywną. Nawiązując do idei trójpodziału władz publicznych, autorzy ci stwierdzali, że administracja to ta część działalności państwa, która nie jest stanowieniem prawa i wymiarem sprawiedliwości. W ich pojęciu administracja stawała się więc synonimem władzy wykonawczej (ujęcie szerokie) lub zarządu wewnętrznego państwa (ujęcie węższe) ${ }^{13}$. W konsekwencji niemieckie piśmiennictwo prawno-administracyjne koncentrowało się przede wszystkim na wskazaniu celów realizowanych przez aparat państwowy oraz wyliczeniu dziedzin i form działalności administracyjnej państwa. To funkcjonalne ujęcie pojęcia „administracja” obejmowało więc $\mathrm{w}$ wydaniu niemieckim wszystkie działania wykonawcze w sferze zarządu wewnętrznego, czyli całą organizatorską działalność państwa w tej dziedzinie ${ }^{14}$.

Również w polskim piśmiennictwie prawno-administracyjnym XIX w. dominowało podejście funkcjonalne do określenia istoty i zakresu pojęcia ,administracja". Autorzy tej miary, co Antoni Okolski, Józef Oczapowski czy Franciszek Ksawery Kasparek - przedstawiciele polskiej szkoły prawa administracyjnego, ujmowali to zagadnienie jako proces realizowania przez państwo jego funkcji zarządzająco-wykonawczych. Terminem „administracja” posługiwali się więc zarówno dla określenia wszystkich (poza ustawodawstwem) przejawów aktywności państwa (administracja sensu largo), jak i zawężając je do pojęcia zarządu wewnętrznego, obejmującego tylko tę jej część, która bezpośrednio zmierzała do stworzenia optymalnych warunków rozwoju jednostki i całego społeczeństwa ${ }^{15}$. Wyróżniali przy tym dwie sfery administracyjnej działalności państwa: 1) reglamentacyjną (nakazowo-zakazową); 2) organizatorską - zmierzającą do rozwoju państwa i dobrobytu obywateli ${ }^{16}$. Rozróżnienie to, wychodzące poza ścisłe utoż-

11 L. von Stein, op. cit., s. 60.

12 R. Gneist, Der Rechtsstaat und die Verwaltungsgerichte in Deutschland, Berlin 1879, s. 6-9.

13 O. Mayer, Deutsches Verwaltungsrecht, Bd. 1, Leipzig 1883, s. 15; W. Jellinek, Verwaltungsrecht, Kiel 1927, s. 3.

14 J. Oczapowski, Recenzja pracy Lorenza von Steina Die Verwaltungslehre, „Czasopismo Poświęcone Prawu i Umiejętnościom Politycznym” 1865, s. 246-251.

15 Według Okolskiego administracja sensu largo obejmuje zarząd siły zbrojnej, politykę zagraniczną, sprawy wewnętrzne, a także zarząd finansów i administrację sądową. Z kolei Kasparek wyłączył z niej administrację wymiaru sprawiedliwości, natomiast Oczapowski uznawał ją za część szeroko rozumianej działalności administracyjnej państwa. Zob. A. Okolski, Wykład prawa administracyjnego oraz prawa administracyjnego obowiazujacego w Królestwie Polskim, t. 1, Warszawa 1880, s. 18; F.K. Kasparek, Prawo polityczne ogólne z uwzględnieniem austriackiego, razem ze wstępną nauką ogólnq o państwie, t. 2, Kraków 1881, s. 618-620; J. Oczapowski, Policyści zeszłego wieku i nowożytna nauka administracji, Warszawa 1882, s. 6.

16 Oczapowski (ibidem, s. 9) wskazywał, że „Zarząd nowożytnego państwa obejmuje w sobie obydwie strony: policyjną ochronną i właściwą administracyjną, gdzie bądź rząd, bądź administra- 
samianie administracji z władzą wykonawczą państwa, było oryginalnym osiągnięciem polskiej myśli administracyjnej, chociaż - jak zauważyła Maria Gromadzka-Grzegorzewska - „stanowiło niewątpliwie nawiązanie do znanych myśli późnych policystów i niektórych autorów rosyjskich XIX w. Zarazem jednak było to wzbogacenie liberalnego podejścia do problemu zadań administracji, sprowadzającego je do funkcji reglamentacyjnych" ${ }^{17}$.

Podobnie jak autorzy francuscy i niemieccy, także większość polskich teoretyków prawa administracyjnego unikała podjęcia próby określenia istoty działalności administracyjnej ${ }^{18}$. Wyjątek stanowił Józef Oczapowski, który definiował pojęcie ,administracja” jako zarząd sprawami publicznymi wykonywany w interesie ogólnospołecznym przez organy administracji państwowej, instytucje samorządowe i stowarzyszenia pełniące $\mathrm{z}$ upoważnienia rządu funkcje zlecone $\mathrm{w}$ zakresie administracji w formie wydawania aktów administracyjnych powszechnie obowiązujących i indywidualnych ${ }^{19}$. W jego ujęciu działalność administracyjna nabierała cech kompleksowego zarządzania wszystkimi sferami życia społecznego i gospodarczego państwa, realizowanego przez państwowe i niepaństwowe jednostki organizacyjne w celu zapewnienia obywatelom korzyści przy poszanowaniu ich podmiotowych praw indywidualnych w zakresie prawa publicznego ${ }^{20}$.

Określając granice działania aparatu administracyjnego, polscy autorzy zgodnie stwierdzali, że prowadzenie działalności administracyjnej we wszystkich jej formach nie wymaga szczegółowego wskazania podstawy prawnej, ale jej realizacja powinna mieścić się $\mathrm{w}$ ramach obowiązującego prawa. Takie podejście do zagadnienia legalizmu funkcjonowania administracji publicznej, w którym administracja funkcjonuje przede wszystkim w granicach, a nie na podstawie prawa, było charakterystyczne bardziej dla prawno-naturalnych konstrukcji państwa prawnego z początku XIX w. niż dla pozytywistycznej dogmatyki końca tego stulecia ${ }^{21}$.

cyjny samorząd wspierają i rozwijają za pomocą przepisów i prawideł (reglements) zasoby kraju czysto fizyczne, czy umysłowe, czy obyczajowe".

17 M. Gromadzka-Grzegorzewska, op. cit., s. 49.

18 Na przykład Okolski (op. cit., s. 15) definiował administrację jako „działalność państwa przejawiającą się w rozmaitej formie i dążącą do rozmaitych celów".

19 J. Oczapowski, Policyści zeszłego wieku..., s. 18-19.

20 Według Oczapowskiego (ibidem, s. 5) „Zarząd wszelki, znamionujący zbiór czynności dokonywanych za rząd, tj. zamiast i w wyręczeniu a uzupełnieniu rządu centralnego, obejmuje wszystkie sprawy administracji krajowej, o ile w obrębie i w kierunku ustaw odnośnych i rozporządzeń organizacji władzy wykonawczej, cała krajowa i obywatelska społeczność pracuje łącznie z rządem, głową władzy wykonawczej, nad ustawodawczymi i wykonawczymi warunkami rozwoju kraju wewnątrz jak i na zewnątrz".

21 Na przykład Kasparek (op. cit., s. 635) ujmował to zagadnienie w następujący sposób: „Działalność administracji przeważnie nie jest pozytywnie ustawami określoną i kierowaną, tylko ujemnie poprzez ustawodawstwo ograniczoną, a jej istota nie polega tylko na przeprowadzeniu zadań państwa bez naruszania ustaw. Jej prawem samoistnym jest wykonać to wszystko, czego interes publiczny i dobro państwa w poszczególnych przypadkach wymagają". 
W rosyjskiej literaturze prawno-administracyjnej pojęcie administracji było utożsamiane z zarządem wewnętrznym państwa ${ }^{22}$. Autorzy rosyjscy różnili się jedynie co do rodzaju instytucji, które określano tym mianem. Jedni, jak Iwan Jefimowicz Andrejewskij, ograniczali to pojęcie wyłącznie do organów administracji rządowej. Inni zaś, jak Aleksandr Iłłarionowicz Wasilczikow, Iwan Trofimowicz Tarasow czy Boris Emmanuiłowicz Nolde, zaliczali doń też instytucje samorządowe ${ }^{23}$. Żaden z pisarzy rosyjskich nie pokusił się o zdefiniowanie pojęcia „administracja”. Dla większości z nich administracja była po prostu jedną z funkcji aparatu państwowego, obejmującego - poza stanowieniem i egzekwowaniem prawa - także wymiar sprawiedliwości. Natomiast niemal wszyscy autorzy rosyjscy starali się określić sfery działalności administracyjnej państwa w dziedzinie zarządu wewnętrznego. Cechą wspólną dla ich twórczości było eksponowanie - wzorem nauki policji - sfery bezpieczeństwa i sfery dobrobytu, ujmowanych jako główne pola aktywności administracyjnej, jak również dominujące przekonanie (poza nielicznymi wyjątkami) o decydującej roli państwa w tej dziedzinie ${ }^{24}$. Jedynie Tarasow, wzorem autorów francuskich, określał działalność administracyjną państwa jako współdziałanie organów rządowych i społecznych, zmierzające do zaspokojenia potrzeb publicznych przy pomocy służb publicznych, samą administrację zaś jako bezpośredniego wykonawcę polityki rządu i realizatora interesów społecznych ${ }^{25}$. W konsekwencji w warunkach rosyjskich nie doszło do wyróżnienia nauki administracji i nauki prawa administracyjnego, które to dziedziny wiedzy zaliczano do szeroko rozumianej nauki prawa państwowego ${ }^{26}$.

22 Tarasow (Uczebnik nauki policejskago prawa, Moskwa 1891, s. 1) pisał wprost, że „Administracją nazywana jest działalność podejmowana w sferze wewnętrznej państwa”.

${ }^{23}$ Posługując się terminem ,policja”, pod pojęciem zarządu wewnętrznego Andrejewskij (Policejskoje prawo, Sankt Petersburg 1874, s. 2) rozumiał wszystkie funkcje władzy państwowej, realizowanej wyłącznie przez organy administracji rządowej, której uosobieniem był monarcha absolutny. Natomiast Tarasow (Uczebnik nauki..., s. 35), opowiadając się za uwzględnieniem czynnika społecznego w zarządzie sprawami publicznymi państwa, wskazywał, że „W minionym okresie administrację postrzegano wyłącznie jako sferę działalności organów rządu, odsuwającego społeczeństwo od wszelkiego udziału w tej działalności. W świetle nowych koncepcji, w stosunkach pomiędzy społeczeństwem a państwem, koniecznością stało się ograniczenie zakresu ingerencji administracji rządowej i dopuszczenie do udziału w zarządzie wewnętrznym również organów społecznych”. Opisując funkcje państwa w dziedzinie zarządu wewnętrznego, Nolde (Oczerki russkago gosudarstwiennago prawa, Sankt Petersburg 1911, s. 266) konkludował: „Samorządność jest formą realizacji funkcji państwa za pomocą niezależnych - mniej lub bardziej - osób i instytucji”.

24 Jeszcze na początku XX stulecia w twórczości autorów rosyjskich można odnaleźć takie policystyczne ujmowanie zadań administracji państwowej, jak np. w pracy Wiktora Wiktorowicza Iwanowskiego (Uczebnik administratiwnago prawa, Kazań 1908, s. 1, 173), który w 1908 r. pisał, że „Pod pojęciem administracji wewnętrznej należy rozumieć ogół przedsięwzięć państwowych, podejmowanych w celu stworzenia warunków dobrobytu i bezpieczeństwa obywateli”.

25 I.T. Tarasow, Kratkij oczerk nauki administratiwnogo prawa, Jarosław 1888, s. 2.

26 „Nauka prawa policyjnego bada relacje prawne wynikające z działalności policyjnej państwa, stąd wniosek, że jest to nauka prawna, która ze względu na podmiot i przedmiot badań pozostaje w bezpośredniej relacji z prawem państwowym" (ibidem, s. 3). 
Problem zdefiniowania prawa administracyjnego powstał równocześnie z instytucjonalnym wyodrębnieniem administracji publicznej jako autonomicznej części aparatu państwowego oraz z określeniem prawnych granic jej działania, organizacji i trybu funkcjonowania. Jak wspomniano wcześniej, nastąpiło to wraz ze stopniową realizacją idei konstytucyjnego państwa prawa, która stała się do końca XIX w. zasadniczą cechą ustroju państwowego większości krajów europejskich. Podstawowym celem wyodrębnienia prawa administracyjnego jako samodzielnej gałęzi prawa było zabezpieczenie jednostki przed arbitralną i despotyczną władzą administracji publicznej, a więc nadanie mu charakteru norm dwustronnie obowiązujących. W dziewiętnastowiecznym piśmiennictwie prawno-administracyjnym prawo administracyjne było definiowane w sposób negatywny - jako dział prawa niemieszczący się w innych gałęziach prawa (tzw. teoria wielkiej reszty), lub pozytywny - jako prawo administracji, prawo służb publicznych lub prawo podmiotów administrujących (kryterium podmiotowe) lub prawo administrowania sprawami publicznymi (kryterium przedmiotowe) ${ }^{27}$.

W doktrynie francuskiej prawo administracyjne ujmowano w sposób podmiotowy jako autonomiczny dział prawa publicznego normujący dwustronne stosunki prawne zachodzące pomiędzy obywatelami a organami państwa, odnoszące się do praw i interesów obywateli (Anselme-Polycarpe Batbie, Léon Aucoc, Louis-Antoine Macarel) ${ }^{28}$. Prawo to tworzyły głównie orzeczenia Rady Stanu i współdziałająca $\mathrm{z}$ nimi doktryna oraz (w mniejszym stopniu) prawo pozytywne i zwyczaje. Poszukiwanie podstawowego kryterium wyodrębnienia prawa admi-

27 Szerzej zagadnienie to zostało omówione w pracy Franciszka Longchampsa de Bériera pt. Współczesne kierunki w nauce prawa administracyjnego na zachodzie Europy (Wrocław 1968, passim). Współczesna nauka prawa administracyjnego nie wypracowała jednolitej pod względem przyjmowanych kryteriów definicji prawa administracyjnego. Proponowane przez poszczególnych autorów definicje tego działu prawa publicznego mają charakter względny - relatywny w stosunku do czasu, miejsca i okoliczności, w jakich są tworzone. Tym niemniej zawierają one pewne wspólne, powtarzające się elementy, które najszerzej uwzględnił w swojej definicji Jerzy Langrod (Instytucje prawa administracyjnego. Zarys części ogólnej, Kraków 1948, s. 226): „Prawo administracyjne to dział prawa publicznego, wewnątrzpaństwowego, obejmujący ogół norm hierarchicznie uporządkowanych, odnoszących się do organizacji i aktywności administracji, a w zasadzie stosowanych - względnie i stanowionych - przez nią, z dwustronną mocą obowiązująca, twórczo, ale w granicach i pod kontrolą prawa”. Przegląd definicji prawa administracyjnego w doktrynie polskiej i obcej zawiera podręcznik autorstwa Z. Duniewskiej, B. Jaworskiej-Dębskiej, R. Michalskiej-Badziak, E. Olejniczak-Szalowskiej, M. Stahl pt. Prawo administracyjne. Pojęcia, instytucje, zasady w teorii i orzecznictwie (Warszawa 2000, s. 33-40).

${ }_{28} \mathrm{~W}$ konsekwencji w nauce francuskiej nie występuje podział prawa administracyjnego na część ogólną i szczególną. Ponadto przyjmowane powszechnie w doktrynie francuskiej wąskie ujęcie prawa administracyjnego ogranicza je niemal wyłącznie do roli regulatora wzajemnych stosunków pomiędzy administracją a obywatelami, sprowadzając pozostałe elementy prawa administracyjnego do zagadnień czysto technicznych, a więc wewnątrzadministracyjnych. Zob. A.-P. Batbie, Precis du cours de droit public et administratif, Paris 1876, s. 4; L. Auccoc, op. cit., s. 15; L.-A. Macarel, op. cit., Vol. 2, s. 641; A.-F. Vivien, op. cit., s. VI-VII. 
nistracyjnego zaowocowało we Francji powstaniem dwóch szkół: szkoły władzy publicznej (pussance publique) i szkoły służby publicznej (service public). Pierwsza z nich, dominująca od czasów napoleońskich aż do końca XIX stulecia, akcentowała element władztwa administracyjnego (tzw. władzę rozkazywania), w które wyposaża administrację prawo administracyjne. W tym klasycznym ujęciu prawo administracyjne stanowiło zespół norm nacechowanych prawną nadrzędnością administracji publicznej w stosunku do obywatela ${ }^{29}$. Natomiast powstała na początku następnego stulecia francuska „szkoła służby publicznej” eksponowała obowiązek praktycznego działania służb publicznych państwa. W jej ujęciu prawo administracyjne to normy służące osiąganiu celów stawianych przed administracją publiczną, czyli dostosowywanie zakresu prawa administracyjnego do ewolucyjnych zmian w potrzebach społecznych (celem prawa administracyjnego jest „służba publiczna”) ${ }^{30}$.

Z kolei w dziewiętnastowiecznej doktrynie niemieckiej, która stosując metodę dogmatyczną, wyodrębniała prawo administracyjne z szeroko rozumianego prawa publicznego, prawo administracyjne było ujmowane tradycyjnie (w oparciu o kryterium przedmiotowe) jako dział prawa normujący ustrój administracji publicznej i jej władcze działanie wobec podmiotów postronnych, nacechowane prawną nadrzędnością (Hoheitliche Gewalt), w którym podstawową formą aktywności administracyjnej jest akt administracyjny (Verwaltungsakt) ${ }^{31}$. W klasycznej, pozytywistycznej nauce niemieckiej pierwszą definicję prawa administracyjnego sformułował Lorenz von Stein, rozumiejący pod tym pojęciem system norm prawnych, na podstawie których realizowana jest administracja wewnętrzna państwa $^{32}$. Jako pierwszy na gruncie niemieckim zastosował - wzorem uczonych francuskich - metodę opisu usystematyzowanego naukowo wedle działów prawa administracyjnego. Szczegółowo przedstawił też ustawodawstwo określające strukturę i formy działania administracji w różnych dziedzinach życia, a następnie pogrupował je w trzy działy prawa administracyjnego, wyodrębnione według kryterium sfer działalności władzy wykonawczej na normy regulujące sferę działania administracji w odniesieniu do: 1) jednostki; 2) życia gospodarczego; 3) życia społecznego ${ }^{33}$. Niepodważalną zasługą Steina było wskazanie funkcji administracji w nowoczesnym państwie prawa i jego naturalnych tendencji roz-

29 Takie stanowisko dominuje np. w następujących pracach: L.-M. Cormenin, Droit administrative, Paris 1840, s. 11; J.-M. de Gérando, op. cit., s. 1; É. Laferrière, Cours de droit public et administratif, Vol. 1, Paris 1854, s. 279.

30 Założenia szkoły służby publicznej wyłożył Léon Duguit w pracy pt. Transformations $d u$ droit public (Paris 1913, passim).

31 F. Longchamps de Bérier, op. cit., s. 120.

32 L. von Stein, op. cit., s. 60.

33 Ibidem, s. 60-65. 
wojowych ${ }^{34}$. Kierunek ten kontynuowali tacy następcy Steina, jak: Georg Meyer, Edgar Lonning, Theodor Inama von Sternegg czy Ludwik Gumplowicz ${ }^{35}$.

Inne podejście do tego problemu prezentował Otto Mayer, uznawany - obok Waltera Jellinka - za twórcę teorii prawa administracyjnego w Niemczech. Przyjmował on, że treścią prawa administracyjnego są stosunki prawne powstające pomiędzy władzą państwową a pojedynczymi jednostkami jako podwładnymi należącymi do związku państwowego ${ }^{36}$. Pozwalało to na wyodrębnienie na gruncie niemieckim prawa administracyjnego tzw. administracji wkraczającej (Eingriffsverwaltung), tj. norm nacechowanych prawną nadrzędnością, od prawa administracyjnego tzw. administracji świadczącej (Leistungsverwaltung), tj. form aktywności administracji pozbawionej tego atrybutu, ale nakierowanej na zaspokajanie podstawowych celów społecznych środkami niewładczymi ${ }^{37}$. Poza tym niewątpliwą zasługą Mayera było stworzenie podstawowych konstrukcji teoretycznych części ogólnej prawa administracyjnego, dokonane w oparciu o analogiczne konstrukcje cywilistyczne dostosowywane do potrzeb prawa publicznego. Ich podstawę stanowił zarówno materiał normatywny obowiązującego prawa administracyjnego, jak i judykatura sądów administracyjnych, ale analizowane przez niego zawsze pod kątem ogólnej konstrukcji prawnej ${ }^{38}$. Stworzony przez Mayera system niemieckiego prawa administracyjnego stał się klasycznym przykładem zastosowania metody formalno-dogmatycznej w nauce prawa administracyjnego, zwłaszcza w jego części ogólnej (metoda opisu usystematyzowanego utrzymała się nadal w części szczegółowej prawa administracyjnego). Wzorzec ten naśladowali niemal wszyscy jego następcy, tacy jak: Fritz Fleiner, Walter Jellinek, Karl Korman, Ernst Bernatzik, Rudolf Hermann von Hernritt czy Josef von Ulbrich ${ }^{39}$.

Na gruncie polskim jedyną próbę zdefiniowania prawa administracyjnego w XIX stuleciu podjął Antoni Okolski. Punktem wyjścia jego rozważań było rozróżnienie administracji sensu largo i administracji sensu stricto, którym przyporządkowywał

34 J. Langrod, La science de l'administration ..., s. 27; M. Gromadzka-Grzegorzewska, op. cit., s. 36; Z. Leoński, Nauka administracji, Warszawa 2000, s. 4.

35 G. Meyer, Lehrbuch des deutsche Verwaltungsrechts, Bd. 1-2, Leipzig 1883-1886; E. Lonning, Lehrbuch des Deutsche Verwaltungsrechts, Leipzig 1884; I. von Sternegg, Verwaltungslehre in Umrissen, Innsbruck 1870; L. Gumplowicz, Rechtsstaat und Sozialismus, Innsbruck 1881.

36 O. Mayer, Deutsches Verwaltungsrecht, Bd. 1, Leipzig 1883, s. IX.

37 F. Longchamps de Bérier, op. cit., s. 121.

38 O. Mayer, Deutsches Verwaltungsrecht, Bd. 1-2, Leipzig 1895-1896. Nie mniej istotna ze względu na zapoznanie nauki niemieckiej z francuskim régime administratif-była praca Mayera pt. Theorie des franzosischen Verwaltungsrecht (Leipzig 1886).

39 F. Fleiner, Institutionen des Deutschen Verwaltungsrechts, Heidelberg 1911; W. Jellinek, op. cit.; K. Korman, Grundzüge eines allgemeinen Teils des öffentlichen Rechts, Berlin 1911; idem, Wörterbuch des deutschen Staats- und Verwaltungsrecht, Berlin 1914; E. Bernatzik, Rechtssprechung und materielle Rechtskraft, Wien 1896; R.H. von Hernritt, Handbuch des Osterreichischen Verfassungrecht, Tübingen 1909; idem, Grundlehren des Verwaltungsrechts, Tübingen 1921; idem, Oesterreichisches Verwaltungsrecht, Tübingen 1925; J. von Ulbrich, Lehrbuch des osterreichischen Verwaltungsrechts, Wien 1903-1904. 
pojęcia prawa administracyjnego w szerszym i węższym znaczeniu. Prawem administracyjnym sensu largo określał ogół norm regulujących działalność państwa w pięciu sferach aktywności, takich jak: stosunki międzynarodowe, finanse, wojsko, administracja wymiaru sprawiedliwości oraz administracja wewnętrzna ${ }^{40} . \mathrm{Z}$ tą ostatnią sferą łączył pojęcie prawa administracyjnego sensu stricto, które według niego było systemem norm określających organizację i zakres funkcjonowania administracji wewnętrznej państwa. W takim ujęciu prawo administracyjne tworzyło zbiór norm, na podstawie których realizowały swoje zadania wszystkie organy władzy państwowej (poza ustawodawczymi i sądowymi), a ich istotą była prawna regulacja stosunków wynikających z relacji zachodzących pomiędzy administracją a obywatelami ${ }^{41}$.

W doktrynie rosyjskiej konstruowanie definicji prawa administracyjnego napotykało na zasadnicze trudności wynikające z braku formalnego podziału władz publicznych w ustroju samowładnej monarchii carów oraz z policystycznego ujmowania zadań państwa w sferze stosunków wewnętrznych. W konsekwencji żaden z autorów rosyjskich nie sformułował definicji prawa administracyjnego. W literaturze rosyjskiej prawo administracyjne utożsamiano przeważnie z wszelkimi normami regulującymi całokształt działalności publicznej państwa, wliczając w to także ustawodawstwo i stosunki międzynarodowe - czyli z prawem państwowym lub rzadziej z prawem zarządu wewnętrznego państwa ${ }^{42}$. W tym ostatnim ujęciu, zbliżającym się do pojęcia prawa administracyjnego sensu largo, mieściły się zarówno normy ustrojowe określające organizację struktur administracyjnych, jak i zadania, formy oraz granice aktywności całego aparatu wykonawczo-administracyjnego państwa ${ }^{43}$. Tym niemniej autorzy rosyjscy podkreślali z naciskiem konieczność przestrzegania zasady legalizmu w działalności administracyjnej państwa oraz postulowali nadanie normom prawa administracyjnego charakteru dwustronnie obowiązującego ${ }^{44}$.

40 Okolski (op. cit., s. 15-16) przeciwstawiał - wzorem autorów francuskich (jak np. Édouard Laferrière) - prawo administracyjne szeroko rozumianemu prawu publicznemu, pisząc: „Prawo administracyjne stanowi część prawa publicznego, określającego w ogóle wszystkie stosunki w państwie, i znajduje się w pewnym przeciwieństwie z prawem państwowym. Pierwsze bowiem zajmuje się państwem w spoczynku, jego organizacją, drugie - państwem w ruchu, jego działalnością, administracją".

${ }^{41}$ „Prawem administracyjnym, w ścisłym tego słowa znaczeniu, jest system przepisów prawnych, za pomocą których państwo tworzy warunki wszechstronnego rozwoju społeczeństwa" (ibidem, s. 19).

42 Na przykład Iwanowskij (op. cit., s. 5) twierdził, że „prawo administracyjne to ogół norm określających wszystkie formy działalności państwa, włączając w to ustawodawstwo, finanse, wojsko, kościół i stosunki międzynarodowe".

43 Według Tarasowa (Uczebnik nauki..., s. 4) „Pozytywnym prawem administracyjnym jest nazywany całokształt postanowień i norm regulujących działalność administracyjną w danym państwie w danym czasie".

44 „Brak prawnego ograniczenia swobody uznania urzędnika niszczy samodzielność obywateli, hamuje ich poczynania i pozbawia ludność poczucia prawa i sprawiedliwości” - A.I. Jelistratow, Osnownyje naczala administratiwnogo prawa, Moskwa 1914, s. 4. 


\section{BIBLIOGRAFIA}

Andrejewskij I.J., Policejskoje prawo, Sankt Petersburg 1874.

Aucoc L., Conferences sur l'administration et le droit administratif, Vol. 1, Paris 1869.

Batbie A.-P., Introduction generale au droit public et administratif, Paris 1876.

Batbie A.-P., Precis du cours de droit public et administratif, Paris 1876.

Bernatzik E., Rechtssprechung und materielle Rechtskraft, Wien 1896.

Cormenin L.-M., Droit administrative, Paris 1840.

Duguit L., Transformations du droit public, Paris 1913.

Duniewska Z., Jaworska-Dębska B., Michalska-Badziak R., Olejniczak-Szalowska E., Stahl M., Prawo administracyjne. Pojęcia, instytucje, zasady w teorii i orzecznictwie, Warszawa 2000.

Dziadzio A., Koncepcja państwa prawa w XIX wieku - idea i rzeczywistość, „Czasopismo Prawno-Historyczne" 2005, nr 1.

Fleiner F., Institutionen des Deutschen Verwaltungsrechts, Heidelberg 1911.

Gérando J.-M. de, Institutes de droit administratif français, Vol. 1, Paris 1842.

Gneist R., Der Rechtsstaat und die Verwaltungsgerichte in Deutschland, Berlin 1879.

Gromadzka-Grzegorzewska M., Narodziny polskich nauk administracyjnych, Warszawa 1985.

Gumplowicz L., Rechtsstaat und Sozialismus, Innsbruck 1881.

Hernritt R.H. von, Grundlehren des Verwaltungsrechts, Tübingen 1921.

Hernritt R.H. von, Handbuch des Osterreichischen Verfassungrecht, Tübingen 1909.

Hernritt R.H. von, Oesterreichisches Verwaltungsrecht, Tübingen 1925.

Iwanowskij W.W., Uczebnik administratiwnago prawa, Kazań 1908.

Izdebski H., Historia administracji, Warszawa 1997.

Izdebski H., Kulesza M., Administracja publiczna. Zagadnienia ogólne, Warszawa 1999.

Jelistratow A.I., Osnownyje naczała administratiwnogo prawa, Moskwa 1914.

Jellinek W., Verwaltungsrecht, Kiel 1927.

Jeżewski J., Dekoncentracja terytorialna administracji jako zasada prawa administracyjnego we Francji, Wrocław 2004.

Kasparek F.K., Prawo polityczne ogólne z uwzględnieniem austriackiego, razem ze wstęna nauka ogólna o państwie, t. 2, Kraków 1881.

Korman K., Grundzüge eines allgemeinen Teils des öffentlichen Rechts, Berlin 1911.

Korman K., Wörterbuch des deutschen Staats- und Verwaltungsrecht, Berlin 1914.

Laferrière É., Cours de droit public et administratif, Vol. 1, Paris 1854.

Langrod J., Instytucje prawa administracyjnego. Zarys części ogólnej, Kraków 1948.

Langrod J., La science de l'administration publique en France aux XIX e. et XX e. siecles, « Revue Administrative » 1961.

Leoński Z., Nauka administracji, Warszawa 2000.

Longchamps de Bérier F., Współczesne kierunki w nauce prawa administracyjnego na zachodzie Europy, Wrocław 1968.

Lonning E., Lehrbuch des Deutsche Verwaltungsrechts, Leipzig 1884.

Macarel L.-A., Cours d'administration et de droit administratif, Vol. 1-2, Paris 1852.

Malec D., Malec J., Historia administracji i myśli administracyjnej, Kraków 2000.

Malec J., Narodziny polskiego prawa administracyjnego, [w:] idem, Studia z dziejów administracji nowożytnej, Kraków 2003.

Mayer O., Deutsches Verwaltungsrecht, Bd. 1, Leipzig 1883.

Mayer O., Deutsches Verwaltungsrecht, Bd. 1-2, Leipzig 1895-1896.

Mayer O., Theorie des franzosischen Verwaltungsrecht, Leipzig 1886.

Meyer G., Lehrbuch des deutsche Verwaltungsrechts, Bd. 1-2, Leipzig 1883-1886.

Nolde B.E., Oczerki russkago gosudarstwiennago prawa, Sankt Petersburg 1911.

Oczapowski J., Policyści zeszłego wieku i nowożytna nauka administracji, Warszawa 1882. 
Oczapowski J., Recenzja pracy Lorenza von Steina Die Verwaltungslehre, „Czasopismo Poświęcone Prawu i Umiejętnościom Politycznym" 1865.

Okolski A., Wykład prawa administracyjnego oraz prawa administracyjnego obowiazujacego w Królestwie Polskim, t. 1, Warszawa 1880.

Stein L. von, Handbuch der Verwaltungslehre, Stuttgart 1865-1884.

Sternegg I. von, Verwaltungslehre in Umrissen, Innsbruck 1870.

Tarasow I.T., Kratkij oczerk nauki administratiwnogo prawa, Jarosław 1888.

Tarasow I.T., Uczebnik nauki policejskago prawa, Moskwa 1891.

Ulbrich J. von, Lehrbuch des osterreichischen Verwaltungsrechts, Wien 1903-1904.

Vivien A.-F., Etudes du droit administratif, Vol. 1, Paris 1859.

Witkowski W., Historia administracji w Polsce 1764-1989, Warszawa 2007.

Zimmermann M., Pojęcie administracji publicznej a ,swobodne uznanie”, Poznań 1959.

\section{SUMMARY}

Development of modern legal-administrative sciences in the $19^{\text {th }}$ century entailed the necessity of specifying their research subject and defining the basic terms. Among the latter ones, defining the terms "administration" and "administrative law", along with specifying their basic features and functions, became the central issue. Attempts to define the term "administration" and specifying its legal essence came across the greatest difficulties. In the subject literature, the twofold approach to this matter was dominating. On tried to define "administration" in terms of object - as individuals or teams of individuals performing administrative functions, bodies or other administrating units, or in terms of subject (functional) - associating the term "administration" with the activity of these individuals or their teams, bodies and administrating units or with the activity of the state and other entities of public authorities. Definitions in terms of subject associated the term "administration" with the team of individuals combined into a certain organizational entirety due to common goals, entrusted with some range of governing powers. In this approach, the starting point was a man acting within a framework of a specific organizational structure. Whereas under the subject definitions, references were made to various spheres of state activity, emphasising that administration is not only an implementation of acts but also a creative activity, being one of the forms of performing the state function, consisting in the direct, practical performance of state tasks.

Keywords: administration; administrative law; administration science; administrative law science

\section{STRESZCZENIE}

Rozwój nowożytnych nauk prawno-administracyjnych w XIX w. pociągnął za sobą konieczność określenia ich przedmiotu badawczego oraz zdefiniowania podstawowych pojęć. Wśród tych ostatnich centralnym zagadnieniem stało się zdefiniowanie pojęć ,,administracja” i „,prawo administracyjne" wraz z określeniem ich podstawowych cech i funkcji. Największe trudności napotykały próby zdefiniowania pojęcia ,administracja” i określenia jego istoty prawnej. W literaturze przedmiotu dominowało dwojakie podejście do tego zagadnienia. Administrację próbowano określać od strony podmiotowej - jako osoby lub zespoły osób wykonujące funkcje administracyjne, organy i inne jednostki administrujące, lub od strony przedmiotowej (funkcjonalnej) - wiążąc pojęcie administracji z aktywnością tych osób, ich zespołów, organów i jednostek administrujących lub też z działalnością państwa i innych podmiotów władzy publicznej. Definicje podmiotowe łączyły pojęcie administracji z zespołem ludzi powiązanym w pewną całość organizacyjną z uwagi na wspólne cele, wyposażonym w pewien zakres uprawnień władczych. W ujęciu tym 
punktem wyjścia był człowiek działający w ramach szczególnego układu organizacyjnego. W ramach definicji przedmiotowych nawiązywano natomiast do różnych sfer aktywności państwa, podkreślając, że administracja to nie tylko wykonywanie ustaw, ale także działalność twórcza, będąca jedną z form realizacji funkcji państwa, polegającą na bezpośrednim, praktycznym wykonywaniu zadań państwa.

Słowa kluczowe: administracja; prawo administracyjne; nauka administracji; nauka prawa administracyjnego 